\title{
Power
}

\section{Stenetta Anthony}

Power can be heard in a still small voice

Echoing throughout the four corners of the earth

Bringing comfort, peace and humility to those it meets.

Power is a strong tower built on the shoulders of men and women who define a nation.

Power is being still and letting others observe your beauty and strength.

Power is engaging in the most minimal task seen by others, but launching others into their destiny.

Power is holding hands with someone who's mourning.

Power is being a First Lady, wife, mother and voice to a nation of women

Where power is shown in not only one's outward appearance but in the stature

of being the First Lady of the United States.

Former First Lady Michelle Obama echoed power in everything she did whether great or small producing timeless power that will transcend time.

\footnotetext{
S. Anthony $(\square)$

National Health and Wellness Program for Academic

Community, Chicago, IL, USA
}

(C) The Author(s) 2018

M. Duster et al. (eds.), Michelle Obama's Impact

on African American Women and Girls,

https://doi.org/10.1007/978-3-319-92468-7_2 